\title{
Comments on an ancient Greek racecourse: finding minimum width annuluses
}

\author{
Saul I. Gass
}

Published online: 28 May 2008

(C) Springer Science+Business Media, LLC. 2008

\section{Erratum to: J Glob Optim DOI 10.1007/s10898-008-9295-9}

The author would like to make the following correction to his paper "Comments on an ancient Greek racecourse: finding minimum width annuluses" (DOI 10.1007/s10898-008-9295-9):

Table 1, Point \#12 should read $\mathrm{X}=24.076 \mathrm{Y}=63.359$.

The online version of the original article can be found under doi:10.1007/s10898-008-9295-9.

\section{S. I. Gass $(\varangle)$}

Decision and Information Technologies, Robert H. Smith School of Business, University of Maryland at College Park, College Park, MD 20742, USA

e-mail: sgass@rhsmith.umd.edu 